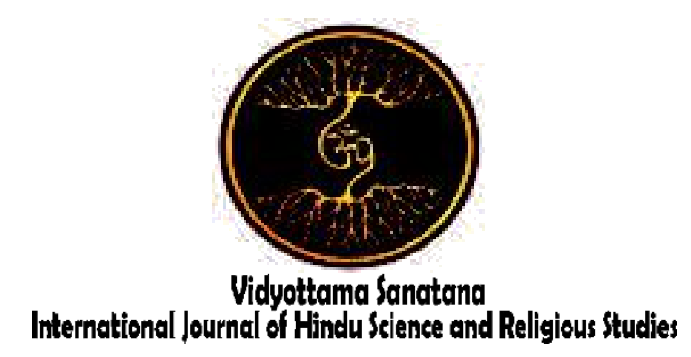

Vol. 4 No. 1 May 2020

\title{
HINDUISM THEOLOGICAL STUDY ON ALBINISM PHENOMENON
}

\author{
By: \\ I Wayan Gama ${ }^{1}$, Kadek Aria Prima Dewi PF ${ }^{2}$ \\ ${ }^{1}$ STKIP Agama Hindu Amlapura \\ ${ }^{2}$ Universitas Hindu Negeri I Gusti Bagus Sugriwa Denpasar \\ E-mail : ${ }^{1}$ wygama8@gmail.com, ${ }^{2}$ primadewipf@ihdn.ac.id
}

Received: March 22, 2020

Accepted: May 21, 2020

Published: May 31, 2020

\begin{abstract}
This study aims to investigate: 1) the views of the Pucang community about albinism, 2) the inheritance pattern of albinism, 3) preventive efforts to prevent the spread of albinism, and 4) the Hinduism theology related to albinism among the Pucang community. The methods used in data collection were interviews, observation, documentation, and literature review. The collected data was analyzed descriptively. There are 9 cases of people with albinism in Desa Adat Pucang. Albino sufferers were born from parents who are close relatives. The people of Desa Adat Pucang believe that albino sufferers were descended from Bethara Pancering Akasa and assume that albino sufferers might be sacrificed as caru (ceremonial offering) during the Panca Bali Krama and Eka Dasa Ludra ceremonies in Besakih Temple. Preventive efforts that can be done to decrease the number of albinism cases are including: 1) avoiding close-family marriages, 2) making 'awig-awig' (rules and regulations) which contains an appeal that closefamily marriages are unfortunate and, 3) genetic counseling for couples who will be married and have been married, and 4) expanding the social interaction and education of Desa Adat Pucang in order to broaden the insights about albinism.
\end{abstract}

Keywords: Hinduism Theology, Albinism, Genetic, Close-family Marriage

\section{INTRODUCTION}

The phenomena of Albinism in some regions are characterized by a variety of community beliefs, which then lead to certain behaviors in interacting with Albino sufferers in their area. In the East African, the Tanzanian community believe that the body parts of Albino-born people can be used as talismans for good luck and wealth, so that humans suffer from Albino will be hunted and 
then mutilated and their limbs can be traded with large profits (Ayu and Nurfa, 2017). Myths or stereotypes related to Albino tend to be negative. In Indonesia, Albinism stereotypes are built in the context of local culture that still believes in occult and magic (Shanaz Nadia Aulia Maharani, IGAA Noviekayati, 2017).

Bali, which are famous with its cultural and religious traditions, also hold a unique Albinism-related beliefs and traditions. Desa Adat Pucang, a village in Kecamatan Kubu, Kabupaten Karangasem, is one of the areas in Bali which has inherrited stereotype towards albino people. People who suffered from albinism are treated very special compared to normal people. The most unique thing done by the Pucang community towards albino sufferers is to conduct a patrol at the border of the village, in order to maintain the safety of albino sufferers during the procession of great ceremony in Besakih Temple. It is believed that albino sufferers are the incarnations of Ida Bathara Pancering Akasa. Ida Bathara Pancering Akasa is a manifestation of God that is worshiped by the local community, which resides in Pura Madya located on the slopes of Mount Agung. If there is a big ceremony held at Besakih Temple, albino sufferers are believed to be the important part of the ceremony in thier previous live, which were used as caru (offering) for ceremonies such as: Panca Wali Krama and Eka Dasa Ludra. This is only the assumption of the local community in Desa Adat Pucang. This could not be scientifically justified. This view has not been proven until now.

Desa Adat Pucang has a limited knowledge about the scientific explanation of the Albinism. Albinism is a cogenital disorder that might be caused by close-family marriages. Marriage with a close relatives was believed to accelerate the emergence of albinism which may expand within the family. If close-family marriages in Desa Adat Pucang are high, then it is likely that the number of albino sufferers will continue to grow. Besides, the community's view will be stronger that albino sufferers are descended from the God. Based on the aformetioned explanation, it is important to conduct a study on albinism in Desa Adat Pucang from the perspective of Hindu Theology.

There are three main research questions that could be formulated as the guidance of the present study. First, what is the opinion of the Pucang community about albinism? Second, what is the inheritance pattern of albinism in Desa Adat Pucang? Third, what are the efforts that can be taken to prevent the emergence of albinism in the Desa Adat Pucang?

This research is expected to provide information to the general public and specifically the Desa Adat Pucang community, that albino is a type of hereditary cogenital disorder which can be prevented.

\section{METHOD}

This is an exploratory research conducted in Desa Adat Pucang with a total population of 697 people. The subjects selected for this study were the albino sufferers and their family in a total of 31 people. They were selected based on purposive sampling technique. Data related to albinism was collected through interview, observation, documentation and literature review. The data is presented in tabular form of observations and pictures of the family tree of albino sufferers. The collected data is then analyzed descriptively according to facts in the field (Atmaja 2000).

\section{FINDINGS AND DISCUSSION \\ Albinism}

Albino is a congenital disorder that could also be occurred in humans, shown by the absence of the color, or melanin pigment in the body. All races have a certain amount of melanin pigment, although some of the white race (especially Scandinavians) only have a small amount of pigment. Pigmentation is produced by certain substances in the body that interact with each other. People who do not have the melanin pigment in their bodies would suffer from albinism. Albino abnormalities are caused by the inability of people to form the enzymes needed to convert 
the amino acid tyrosine to beta-3, 4dihydroxyphenylalanin to subsequently be converted to melanin (Suryo 2011).

The word albino comes from the Greek 'albus', which means white. The body of people with albino is all white with white hair all over his body. Even the internal organ such as the brain and spinal cord are white. Albinism is a congenital disorder. Albinism could be passed on from parents to children. It is rarely inherited from the father or mother only. There are other genetic mutations associated with albino, but all of them lead to changes in melanin production in the body. Because albino sufferers do not have the melanin pigment (serves to protect the skin from ultraviolet radiation coming from the sun), they suffer from sunburn, which is not a problem for ordinary people.

In normal people, the melanin pigment is formed from the amino acid tyrosine by certain enzymes in the body. Albino sufferers do not have the enzyme that functions to convert tyrosine into beta-3, 4dihydroxyphenylanin for later being converted into melanin pigment. The formation of enzymes that convert tyrosine to melanin is determined by gene A, so normal people can have AA or Aa genotypes while albino people do not have the dominant $\mathrm{A}$ gene so the homozygote is aa.

The genes that cause albinism are located in autosomal cells, so the inheritance of the albinism occurs in an autosomal recessive manner. Because of that, albinism can be found in men and women (Suryo 2011). The possibility of the emergence of albinism in families whose parents are carriers of albinism is $25 \%$. The chances of albinism will increase if one of his parents is a sufferer. Marriage of an albino mother to a father who is a carrier (albino carrier) or vice versa brings a $50 \%$ chance that her child will suffer from albino and $50 \%$ of her child will be carrier (Bakar, 2009). In general, the frequency of emergence of albinism in the world is 1 : 20,000 births, but in Africa it can reach 1: 5000 births that are sufferers of albinism. The highest albino growth in the world is in Ukerewe, Tanzania (Wardhana 2006).

\section{The Marital Pattern in Desa Adat Pucang}

Desa Adat Pucang is located in Desa

Ban, Kecamatan Kubu, Kabupaten Karangasem. The geographical condition is hilly, which is quite isolated from other traditional villages (Monography Desa Ban, 2009). In terms of the economic situation, the community is in low income level. Residential houses are mostly semi permanent. However, there are also some who are in the middle economy level. The education level of the Desa Adat Pucang community is low.

Desa Adat Pucang still reflects traditional village life. There are two community groups who live side by side in Pucang, Dadya Dukuh and Dadya Pasek (Kusuma, 1986; Astra, et al 2001). The total population of Pucang Village is 697 people, consisting of 353 men and 344 women. There are 117 families in this village (Penyusun, 2009).

The pattern of marriages formed in Desa Adat Pucang tend to be with the closest relatives so that the level of family marriages is very high. Moreover, there are no awigawig (regulations) that prohibit marriages with families in the traditional village. In Hindu perspective, close-family marriage is unfortunated and it is prohibited (Puja 2000). In Hinduism marriage with close relatives (family) such as cousins is not allowed. Marriage which is prohibited according to Hinduism is the marriage of sapinda as mentioned in Menawa Dharmasastra, verses 171,172 and 173 as follows.

\section{Verse 171 states;}

"Someone who has engaged in intercourse with his biological sister, with a friend's wife or with a wife of a child, with an unmarried woman and with a low-class woman (prostitute), must do a penance for violating the bed of the teacher (guru tapa)".

Verse 172 states;

"Someone who has enggaged in intercourse with the father's sister's child (cousins), who is almost the same as his sister, the daughter of the mother's sister 
or the son of the mother's brother, is purified by doing candrayana tapa".

Verse 173 states;

"Wise people must not marry the woman above, they must not marry her because they are sapinda (close-family), and those who marry her will fall in contempt/misfortuned".

Based on the above quote (verse 172) marriage with close-family according to Hindu teachings is prohibited. Anyone who violates will be suffering from a despicable fall. One of the aforementioned sufferings is the emergence of hereditary diseases in the family one of which is albinism. The Balinese Hindu community calls a marriage with a close relative, e.g., cousin, is called a misfortuned marriage or mekedeng-kedengan engad.

The results of the observations in found that there are 9 people are suffering from albinism with a range of ages 5 years to 25 years. The physical symptoms are including white hair, white skin all over the body, pink eyes, and feel glare during the day. Based on genealogical tracking, the inheritance pattern of albinism in Pucang village can be seen in the following Figure.

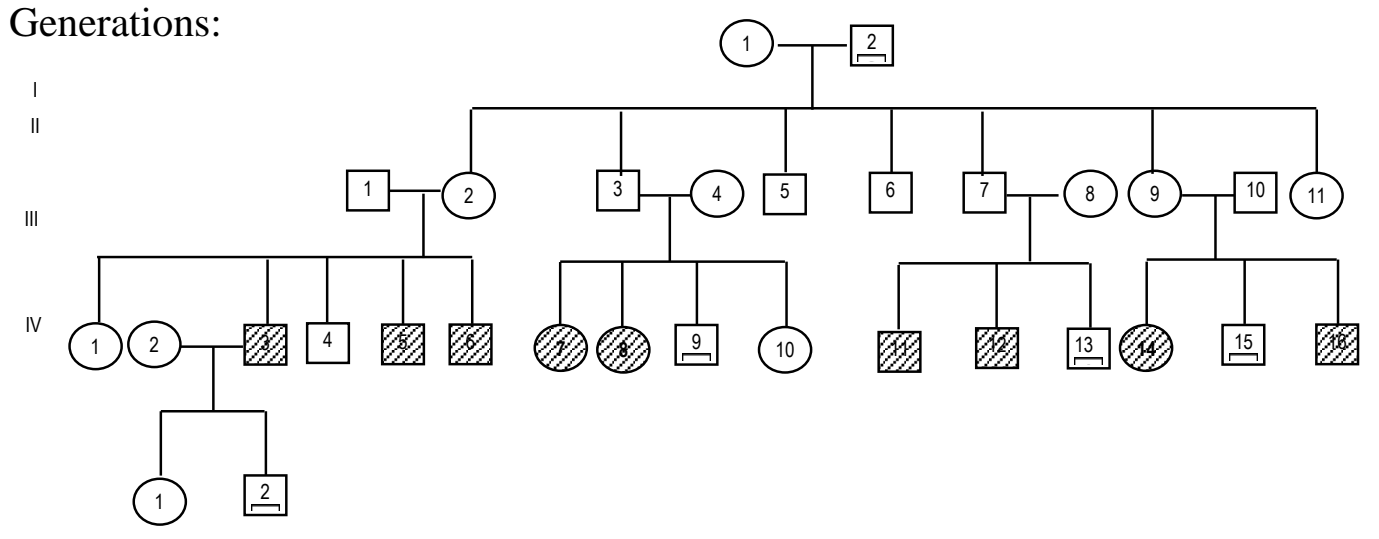

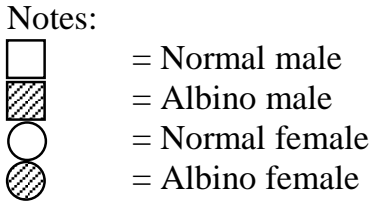

The names:

I.1. Ni Nengah Duduk

I.2. I Nyoman Koyogan

II.1. I Nengah Tambe, 2 Ni Wayan Sanur, 3. I Wayan Sisa, 4, Ni Nengah Sami, 5, Nengah Rantun, 6. Nyoman Suwetra, 7. Ni Nengah Sukerti, 8. Ni Ketut Kribis,

9. I Wayan Landuh, 10. Ni Wayan Pupuk, 11. Mibek

III.1. Ni Wayan Suati, 2. Ni Wayan Marning, 3. I Nengah Wangsa, 4. Ni Nyoman Rami, 5. I Ketut Tambun, 6. I Nengah Karsa, 7. Ni Wayan eka Yani (kapul), 8. Ni Nengah Lia (Lempas), 9. Nyoman Astawa, 10. Ketut Rimi, 11. Wayan Parta, 12. Nengah Karpa Naka, 13. Winda Yani.

IV. 1. Ni Wayan Sumi, 2. Nengah Wirawan

\section{The Community Perception on Albinism in Desa Adat Pucang}

Based on the results of interviews, it was found that the community of Pucang village do not have enough knowledge about albinism as a congenital disorder. Villagers consider albino sufferers to be the descendants of God, namely Bathara Pancering Akasa. Bathara Pancering Akasa is worshipped in Pura Madya in Pucang 
Village, located on the slopes of Mount Agung. This belief has been accepted for generations and no one has dared to refute and change the views of these communities to date. The results of an interview with I Wayan Sisa who is a community leader in Pucang Village found that no one dared to exclude or even denounce the sufferers, because they believed that if they insult or denounce albino people they would get a curse. Even the offspring of the people who insult the albino will suffer from albino also.

All married couples in Pucang Village do not want to have albino children. Based on the interviews with Ni Nengah Sami and Ni Wayan Sanur it is known that mothers, especially those who are pregnant, are generally worried that their children will be born albino. It was said that pregnant women who got a dream of being given kasa (white gause) by Bathara Pancering Akasa will have an albino child.

Besides the perception that albino sufferers are the descendants of Bathara, the local community also perceived that albino people are used as caru (offerings) at the Besakih Temple during a big religious ceremonies such as Panca Wali Krama and Eka Dasa Ludra. The albino sufferers receive strict guard from the villagers during those ceremonies. This perception have an impact on religious events in the area. None of the Pucang Village residents dare to pray to Besakih Temple every Panca Wali Krama and Eka Dasa Ludra Ceremony. These two big ceremonies seem very scary to the people of Pucang. The society's strong perception about the albinism religious elements could not be changed easily. Although the doctors already states that albino is a hereditary cases.

\section{The Inheritance Pattern of Albinism in Desa Adat Pucang}

Based on the lineage chart that can be seen in Figure 1, albino sufferers in the Pucang Village come from one large family, namely the family of I Nengah Koyogan. Albino sufferers in Pucang are relatives, such as cousin. All albino sufferers were born from married couples who are carriers (albino gene carriers). From this family tree, it can be ascertained that parents of albino sufferers are carriers namely I Nengah Tamba, Ni Wayan Sanur, I Wayan Sisa, Ni Nengah Sami, Ni Nengah Sukerti, Ketut Kribis, I Wayan Landuh and Ni Wayan Sopak. Husband and wife who are carriers would have the opportunity to have albino children by $25 \%$. A married couple who are both sufferers would have $100 \%$ chance to have albino children (Suryo 2011).

The couples of a sufferer and a career would have $50 \%$ chance of their children suffering from albino. If an albino sufferer marry with normal person without any record as being a albino gene carrier, they would have $100 \%$ chance to have normal children. I Nengah Wangsa (an albino sufferer), who married with Ni Wayan Marning (normal; no record of albino gene carrier), All of their children are normal.

Therefore, the family tree and the result of interviews confirm that albinism is a hereditary case. Marriage with a close-relative (sapinda) accelerates the emergence of albino sufferer in the family.

Hinduism basically prohibits marriages with close relatives, for example by marrying a cousin. In the book of Menawa Dharmasastra it is stated that if a marriage with a close relative is carried out it will bring suffering. There are several efforts that can be taken to prevent the emergence of albinism in Pucang Village, such as:

1. Avoiding marriages with close relatives. Especially with families who have the same history of albino sufferers.

2. Avoiding partners who are suffered from albino.

3. Expanding the association of young people in the Pucang Village.

4. Improve the quality of children's education in Pucang Village especially about albinism.

5. Conduct genetic counseling for couples who will or have been married.

\section{Albinism based on Hinduism Theology}

The concept of God (theology) in Hindu terminology is called Brahma Widya, the knowledge about Brahman (God). The 
philosophical view of God is different from the view of religion. Philosophycal views of God is based on the rational mind approach, while religion views of God is based on the beliefs of its adherents. In Hinduism the view of God is stated as follows: 1) Animism is a belief in the existence of a spirit in the universe. 2) Dynamism is a belief in the forces of nature. This natural force can be in any form. In the context of God's dynamism, God is also believed to be the super natural power. 3) Totemism is the belief that animals have power (supernatural powers) or sacred animals. Hindu teachings believe that cows are sacred animals so they are respected. In Hindu religious view the cow is called 'mother', because the cow gives milk to human life. 4) Polytheism is a belief about the existence of many Gods. The form of God varies according to their beliefs. Pucang people call the name of God as Ida Bethara Pancering Akasa. 5) Natural Polytheism is the key to the existence of many Gods ruling various natural regions. In the Hindu concept there is a God of the sun, moon, wind, earth and so on. In the teachings of Hindu God there are many according to their manifestations. Lord of the seas is called 'Dewa Waruna'. God with manifestations as creators is called 'Dewa Brahma'. God whose function is to protect (preserve) all living things in the universe is called Vishnu. God whose job is to return all elements of life to their original nature is called Shiva. That is the concept of Natural Polytheism's belief in Hinduism. 6) Monotheism is a belief in God Almighty (one God) in the concept of Hindu Monotheism is divided into Transcendent Monotheism and Immanent Monotheism. Transcendent monotheism is the Hindu view that the Almighty God is far from His creation (human). God is almighty, so that it cannot be reached by the human mind. So that, humans can get closer to God, justified by using God's sacred symbols (prelingga / pretima). Immanent monotheism is a belief that God Almighty as the creator of the universe and its contents, and God is within his creation. Hindus say that God is within him. Thus the view of God according to Hindu studies.
Theology or Brahma Widya is the knowledge of God. Theos (Greek) which means God, and logos means knowledge. In Sanskrit literature and various Hindu books, the study of divinity in Hinduism is called Brahma Widya or Brahma Tattwa Jnana (Donder 2005). The word Brahman means God, and Tattwa means the essence of Tat (that is, God in the form of Nirguna Brahman). The use of the word Tat as a word that means God, is to designate God to be far from humans. To understand more about the symbols of God, we will first describe the nature of God in Hinduism (Titib 2012).

In theology, there are various teachings (isms) that describe the relationship of human belief with God, such as: Monotheism, Polytheism, Pantheism, Monism, and Henotheism. Ism here means belief or teaching (Monier 1993). Besides, there are also other isms such as: Animism, Spiritism, Totenism, Magism, which basically discusses various aspects of people's beliefs about spirits that affect human life.

Based on the explanation above, Hinduism is the closest religion to those isms, as Hinduism is often called: Polytheism, which means many Gods, Dynamism and Pantheism which means recognizing the power of nature or supernatural powers. Hinduism is a religion that Monistic, which can be found in both the Darsana and the Puranas. However, Hindu Theology, if it is associated with Sruti Vedas sources, is Monotheism, but in Smerti Vedas, such as Itihasa and Puranas, many terms of God are found, so Hinduism is often called the Polytheism Religion.

Although Brahma Widya is known as the knowledge of God, it does not mean that God has been known to humans as well as knowing other things. To help human difficulties in understanding the unthinkable God (acintia) wise people teach in two ways, called Nirguna Brahma philosophy and Saguna Brahma. Nirguna Brahma means God without attributes, without nature, without form. Saguna Brahma means that God is envisioned as having a certain form (Donder 2005). 
In the context of present study, religious behavior in Pucang Village is heavily influenced by Saguna Brahma's theological understanding by bringing up various attributes, signs, symbols and forms of God, which are presented to strengthen their beliefs about God in local terms there called Bethara Pancering Akasa. When viewed from the meaning of isms, dynamism and pantheism have a big influence, moreover being associated with the existence of albino sufferers.

People's description of God with transcendence or immanence can be understood, to help human difficulties adore something that is not manifested. The scriptures justify man worshiping what is manifested. So that, the Pucang people call their God as Bethara Pancering Akasa. The behavior displayed by the Pucang community is a form of devotion according to the situation and conditions and the mental attitude of the local community. In theory there is a depiction of a Transcendental God, and a depiction of an Immanent God. For his practical purposes God is described according to the human mind emperistically. The imitation of God is essentially incompatible with the Sruti Vedas. But for the sake of adherents, it is not prohibited as long as it is truly believed sincerely. Based on the Saguna Brahma philosophy, the portrayal of God as understood causes the nature of God to be described as human, measured according to human measurements, causing the image of God to be Pantheistic, God like humans (Purusa-Pradana / Lanang-Istri / ManWoman). The depiction of God in human self language, God is often depicted symbolically, such as in the form of a statue, in the form of an 'Om' script and in the form of the Sun.

The form of human devotion / bhakti based on their mental acts, can be devided into : Anuraga bhakti, Dasyam Bhakti, Sokhyam Bhakti, Mathura Bhakti, Shanta Bhakti dan Watsalya Bhakti (Jendra 1993). Anuraga Bhakti is a form of devotion that is driven by love. Like the love of husband and wife. Brothers and sisters love. Dasyam Bhakti is a form of devotion based on a high sense of devotion. In modern times Dasyam Bhakti is almost similar to the relationship that occurs between superiors and subordinates (bosses and employees). Sokhyam Bhakti, a form of devotion based on a sense of friendship. Mathura Bhakti is a form of devotion based on a loving relationship between a lover and a loved one. Shanta Bhakti is a form of devotion based on sincerity, pleasure, dedication and mutual assistance. Shanta Bhakti is shown by many adherents of spiritual teachings. Watsalya Bhakti is a form of devotion based on the love of a mother with her child. A sense of love as shown by the albino sufferers when worshipping Bethara Pancering Akasa, during the ceremony at the Pura Madya Pucang Village. All of the culture of ideas, and the culture of patterned behavior that is shown as total activity at ceremonial celebrations at Pura Madya in Pucang are various forms of devotion attached to the behavior of albino sufferers.

For the term God in Hindu theology such as: Brahma Sutra, Janmadhyasya yatah which means that God is the origin of all this. Reg Weda I.164.46 : Ekam Sad Wipra Bahudha Wadanti, Agni Yamam Matariswanam Ahuh: Wise man called the Almighty God with many names: Agni, Yama, Matariswa, Mahanirwana Tatra :Sat Citta Ananda Brahman: (Truly) God is the truth of infinite knowledge. Brahma Sutra :Tad Awyaktam, Aha Hi: (truly) God is the unspeakable, so (the scriptures) have said.

\section{CONCLUSION}

Based on the above explanation, some conclusions can be drawn as follows; 1) The people of Desa Adat Pucang have the view that albino sufferers are the descendants of Bathara Pancaring Akasa and albino sufferers can be used as caru during the Panca Wali Krama and Eka Dasa Ludra Ceremony in Besakih temple. 2) The albino sufferer in the Desa Adat Pucang was inherited from a large family who did a clore-family marriage. 3) Preventive acts that can be carried out to prevent the emergence of albinism in the Desa Adat Pucang are avoiding close-family marriages, avoiding marriages with or 
between albino sufferers, expanding relationships among young people, increasing the education level of the Pucang community and conducting genetic counseling. Albino sufferers get a special position in Desa Adat Pucang due to the belief that Albino sufferers are descendants of Bhatara Pancering Akasa, beliefs about albino sufferers are one of the means of offering (caru) for large ceremony in Besakih causing people to be afraid of having Albino children, but do not know the cause of the Albino phenomenon itself, which is actually caused by close-family marriages.

\section{REFERENCES}

Atmaja, I W. B. (2000). Metodologi Penelitian. SIngaraja: IKIP Negeri SIngaraja.

Ayu, D. \& Nurfa, V. (2017). Kurangnya Komitmen Negara Dan Organisasi Internasional Dalam Perlidungan Hak Asasi Manusia Terhadap Albino Di Tanzania. 6(1): 87-95.

Donder, I K. (2005). Esensi Bunyi Gambelan Dalam Prosesi Ritual Hindu. Surabaya:
Paramita.

Jendra, I W. (1993). Latihan Meditasi Untuk Kesehatan. Bali Post.

Monier. (1993). Sosiologi Agama. Surabaya: Paramita.

Penyusun, T. (2009). Monografi Desa Kecamatan Kubu. Kab. Karangasem. Amlapura.

Puja, I G. (2000). Manawa Dharmasastra. Surabaya: Paramitha.

Maharani, S. N. A., Noviekayati, I. G. A. A., \& Meiyuntariningsih, T. (2017). Efektivitas Expressive Writing Therapy dalam Menurunkan Tingkat Stress pada Remaja dengan Albino Ditinjau dari Tipe Kepribadian Introvert dan Ekstrovert. Persona: Jurnal Psikologi Indonesia, 6(2), 98-110.

Suryo, Ir. (2011). "Genetika Manusia." Genetika Manusia.

Titib, I M. (2012). Weda. Jakarta: Direktorat Jenderal Bimas Hindu Kementerian Agama RI.

Wardhana. (2006). Konseling Genetik. In Denpasar: Universitas Udayana 